\title{
Discovery, Modification and Production of T4 Lysozyme for Industrial and Medical Uses
}

\author{
Alaa Alhazmi ${ }^{1}$, Johnathan Warren Stevenson ${ }^{1}$, Samuel Amartey ${ }^{2} \&$ Wensheng Qin $^{1}$ \\ ${ }^{1}$ Department of Biology, Lakehead University, 955 Oliver Road, Thunder Bay, ON, P7B 5E1, Canada \\ ${ }^{2}$ Division of Biology, Imperial College of Science, Technology and Medicine, London, E8 1PQ, UK \\ Correspondence: Wensheng Qin, Department of Biology, Lakehead University, Thunder Bay, ON., P7B 5E1, \\ Canada. Tel: 1-807-343 8467. Email: wqin@lakeheadu.ca
}

*The authors contribute equally to the work

\author{
Received: June 6, 2014 Accepted: June 28, 2014 Online Published: July 13, 2014 \\ doi:10.5539/ijb.v6n4p45 URL: http://dx.doi.org/10.5539/ijb.v6n4p45
}

\begin{abstract}
Lysozyme has attracted immense attention as an antimicrobial agent because of its ability to lyse the bacterial cell wall. It is found in a wide variety of body fluids and in cells of the innate immune system. Lysozyme can act as muramidase or as a Cationic Antimicrobial Peptide (CAMP). Lysozyme has many applications in the medical and industrial fields. Based on enzyme nomenclature, lysozyme is classified as a glycosylase under the group hydrolases. This manuscript covers a fundamental review of lysozyme in terms of discovery, history, functions and various sources and types of lysozyme. The biological and molecular structure is discussed as well as notable bioengineering and protein modifications. Furthermore, the mechanisms of resistance to lysozyme in microorganisms have also been discussed. Lastly, different methods that have been developed for detecting and measuring the activity of lysozyme are outlined. Although, a recombinant lysozyme has not yet been produced, several studies have attempted to generate a modified lysozyme either for large-scale production or that which is more suitable for industrialization purposes.
\end{abstract}

Keywords: antimicrobial, applications, biomolecular structure and functions, detection, thermostability

\section{History}

Lysozyme (1, 4- $N$-acetylmuramidase, E.C.3.2.1.17) is a small cationic protein first reported by Laschtschenko in 1909 (Burgess, 1973). However, the discovery of lysozyme is attributed to Alexander Fleming who reported that lysozyme was a "powerful bacteriolytic element found in human tissues and secretions" (Fleming, 1922). Fleming was at the time suffering from a cold and he allowed drops of his nasal secretions to fall onto an agar culture plate that was thickly colonized with bacteria. The plates were then incubated at a certain temperature for a number of hours, after which radial inhibition beyond the nasal mucus on the plate was observed. This experiment was later termed the lysoplate and it was concluded that the nasal secretions contained an enzyme capable of bacterial lysis. This enzyme was named lysozyme.

With the success of his preliminary experiment, Fleming (1922) continued to work with lysozyme, testing its antibacterial properties with several different bacteria. He reported the discovery of a small round bacterium Micrococcus lysodeikticus (now referred to as Micrococcus luteus) which was particularly vulnerable to lysozyme. He later diluted the nasal secretions in saline and added the solutions to a thick suspension of the M. luteus. Within minutes of incubation at $37^{\circ} \mathrm{C}$ the opaque bacterial solution had cleared. This experiment was later termed the Turbidimetric test. Fleming and Allison also showed increased levels of lysozyme in patients with pyogenic infections (pus producing) such as meningitis, the first indication that lysozyme could be a marker for sepsis (Fleming \& Allison, 1927).

Since Fleming's initial discovery of lysozyme in tears and nasal secretions, many early studies have explored its various characteristics. For example, Wolff (1927) reported on its chemistry; Hoder (1931) its relation to immunology; Anderson (1932) its importance in vitamin A deficiency; Corper (1932) its relation to tuberculosis; Meyer et al. (1936a) its purification and properties; and Meyer et al. (1936b) combined with Daly (1938) the mechanism of its action. It is a paramount component of innate immunity due to its antibacterial, antiviral, 
antitumor and immune modulatory activities, such as anti-inflammation and immunomodulation (Helal et al., 2010). There has also been interest in lysozyme as a "natural" antibiotic. Commercially, lysozyme is produced from chicken egg whites. While T4 lysozyme (T4L) originates from phage T4, until now, there has been no commercial production of T4L ("BRI of CAAS," 2011, p. 4). However, in the future, the development of advanced technology in molecular biology and fermentation could facilitate large scale production of T4L for industrial and medical purposes.

\section{Biomolecular Structure and Function}

\subsection{Biological and Molecular Functions of Lysozyme}

Lysozyme is a bacteriolytic enzyme that has the ability to hydrolyze glycosidic bonds of 1,4-beta-linkages between $N$-acetylglucosamine $(N A G)$ and $N$-acetylmuramic acid $(N A M)$ in peptidoglycan (PG), which is present in the cell walls of prokaryotes (e.g., bacteria) (Mir, 1977; Akinalp et al., 2007) (Figure 1). In addition, its lytic activity has also been reported to inhibit viruses and eukaryotes, including fungi and parasites, in the absence of typical PG in their cell walls. However, the lysis of yeast and mould has been explained by the presence of an important component of their cell walls called chitin, which has the same $\beta-(1-4)$ glycosidic bonds as the bacterial PG, except that chitin links two $N A G$ residues rather than $N A G$ and $N A M$; this means that lysozyme also possesses chitinase activity (Figure 2). Chitin is present in insects, crustaceans and fungi cell walls. Furthermore, the inhibition of Entamoeba histolytica by lysozyme can be explained by the presence in its membrane of lipopeptidophosphoglycan (LPPG), which can react with the enzyme in a similar manner as the PG (Benkerroum et al., 2008).

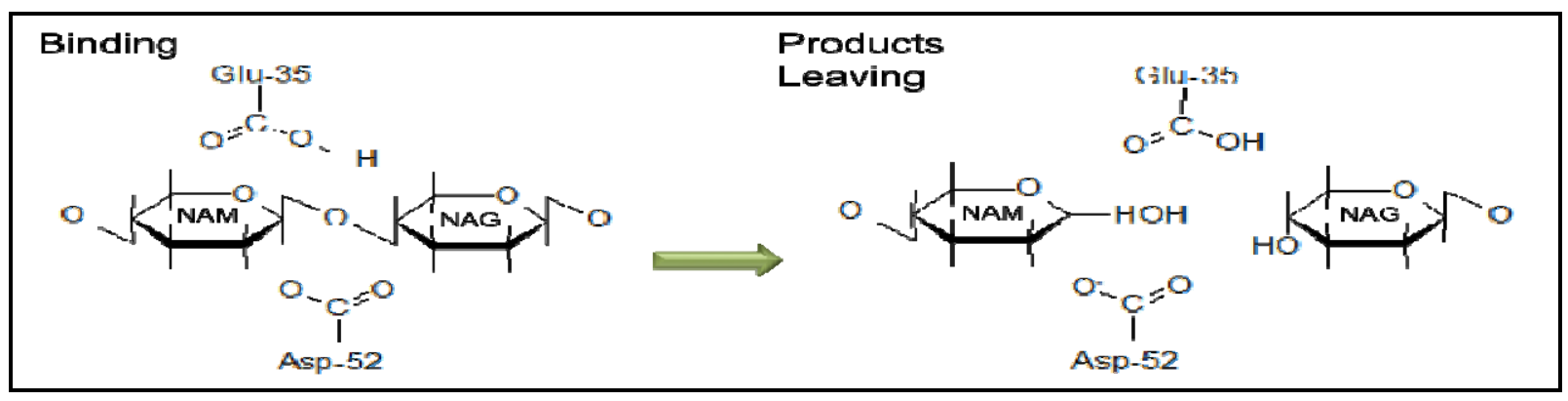

Figure 1. The catalytic mechanism of lysozyme. The substitution on the sugar rings have been omitted to improve the clarity of the diagram. The diagram was drawn by using ACD/ChemSketch Freeware software, a free comprehensive chemical drawing package (http://www.acdlabs.com). It was originally adapted from (Smith \& Wood, 1991)
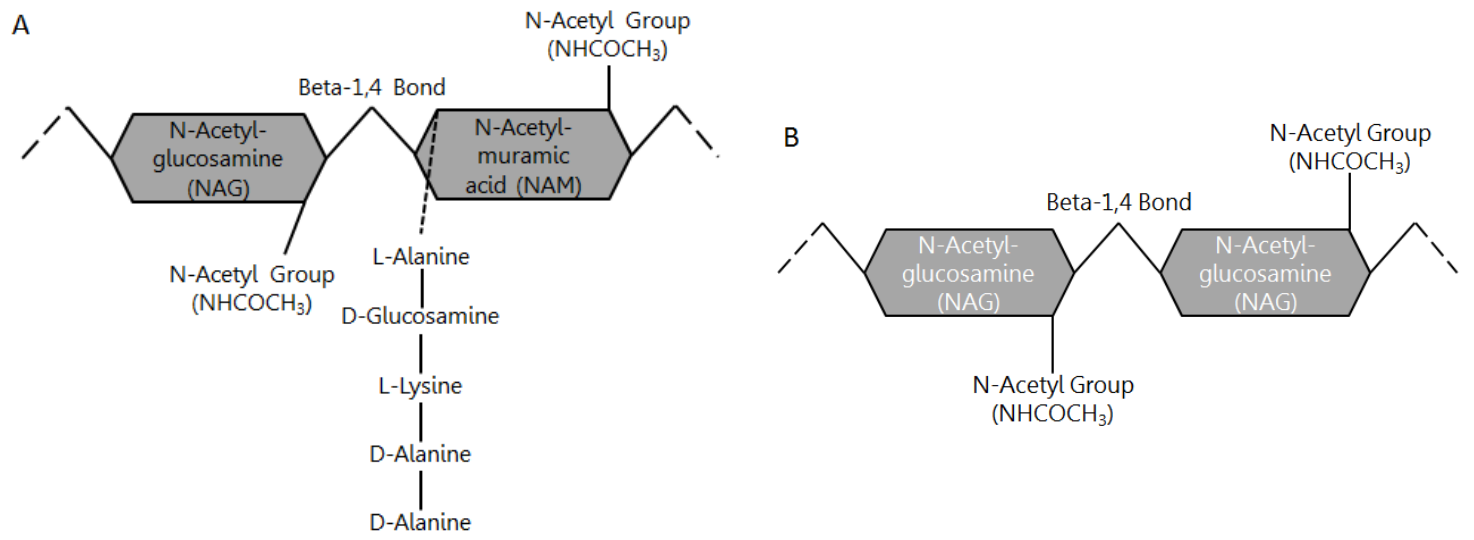

Figure 2. Simplistic representations of (A) peptidoglycan monomer and (B) chitin monomer. The beta-1,4 glycosidic bond between subunits is highlighted. Important substituents to the base glucosamine subunits are also highlighted, with other details left out to improve the clarity of this figure 
Along with chitinase, lysozyme characterizes a significant class of polysaccharide-hydrolyzing enzymes. The chemical similarity between the two-polysaccharide substrates leads to some lysozymes being able to hydrolyze chitin, but they do so less effectively. Therefore, some lysozymes can be considered good chitinases, yet they have no obvious amino acid sequence similarities (Wohlkonig et al., 2010).

The antimicrobial activity of lysozyme has been extensively demonstrated in vitro or in physiological fluids and secretions, including milk, blood serum, saliva and urine. The antimicrobial activity of milk lysozyme, part of the non-specific innate defense mechanism, is also well established. Specifically, it acts independently by lysing sensitive bacteria or acts as a component of complex immunological reactions to enhance the phagocytosis of bacteria by macrophages thereby contributing to the innate protection from milk spoilage after drawing (i.e., bacteriostasis period) (Benkerroum et al., 2008). Lysozyme also has a Cationic Antimicrobial Peptide (CAMP) function that leads to bacterial death via the destabilization of the cytoplasmic membrane (Le Jeune et al., 2010).

Lysozyme is recognized to be non-dialyzable, soluble in water and a weak saline, insoluble in alcohol and ether, resistant to heat and desiccation and stable at room temperature (Burgess, 1973); it has also been demonstrated to be as stable at acidic $\mathrm{pH}$ and labile at alkaline $\mathrm{pH}$ (Jolles, 1969). Understanding the biochemistry and genetics of lysozyme enzymes, their phylogenetic relationships and methods of estimation will make them very useful in a variety of processes in the future (Patil et al., 2000).

\subsection{The Structure of Lysozyme}

Lysozyme is one of the first enzymes for which the X-ray structure was determined (Blake et al., 1965). Furthermore, several classes of lysozymes have been identified based on their sequence similarities. The best known include C-type (chicken-type), G-type (goose-type) and V-type (viral type) (Wohlkonig et al., 2010). Despite the variability in the genetic sequence of the classes of lysozyme, amino acids of the catalytic center of active sites are well conserved to maintain the hydrolytic function of the enzyme from different sources. In particular, glutamic acid (Glu35) and aspartic acid (Asp52) residues are directly involved in the breakdown of the glycosidic bond between $N A G$ and $N A M$. As a result their presence in the catalytic center is crucial for the hydrolytic activity of the enzyme. Glutamic acid acts as a proton donor through the free carbonyl group of its side chain, while aspartic acid acts as a nucleophile that generates a glycosyl-enzyme intermediate, which then reacts with a water molecule to give the product of hydrolysis and release the enzyme unchanged (Figure 3). However, the amino acid sequence of known lysozyme has revealed that aspartic acid is not consistently present in the active sites of lysozyme molecules. In contrast, substitution of glutamic acid has resulted in a complete inactivation of the enzyme, which confirms the critical role of this amino acid in the enzymatic activity of lysozyme, regardless of its origin or the class to which it belongs (Benkerroum, 2008).

Furthermore, there are two structural domains and one polysaccharide ligand involved in the hydrolysis of glycosidic bonds. The structural domains are typically an $\alpha$-helix and a $\beta$-sheet that form a cleft in which the ligand binds with polysaccharide at the active sites Glu35 and Asp52 (Figure 4) (Alberts et al., 2010). Once the polysaccharide binds to the active sites the enzyme begins to hydrolyze available glycosidic bonds within the polysaccharide.

The structure of T4 lysozyme is well characterized, the backbone of T4L has two separate domains, the N-terminal and the C-terminal, which are joined by a long $\alpha$-helical chain (Baase et al., 2010). Structural studies have shown that the two domains form a pocket that opens and closes to facilitate ligand binding and release (Ramanathan et al., 2011). The native structure of this protein has been determined to $1.7 \AA$ resolution by X-ray crystallography (Poteete et al., 1997). Also, T4L is notably devoid of disulphide bridges since it only has two Cys residues, located in positions 48 and 97 , locations that prevent interaction.

The potential of lysozyme has attracted considerable interest over many years (Gorin et al., 1971). For example, hen egg white lysozyme (HEWL) is very similar to human lysozyme; it has 129 amino acids, while human lysozyme has $\sim 148$ amino acids and is three to four times more reactive as tested by the turbidimetric test (Jolles, 1969; Lollike et al., 1995). However, due to its structural similarity, availability and inexpensiveness, HEWL has been used as a model for human lysozyme experiments, making it one of the most studied enzymes (Lollike et al., 1995).

Studies determining the structure of lysozymes showed that HEWL, T4 phage lysozyme (T4L) and goose egg white lysozyme (GEWL) have an overall similar three-dimensional structure, but drastically different amino acid sequences. Among the different lysozymes, the only highly conserved element within the active site is a glutamic acid residue (Glu-35 in HEWL, Glu-11 in T4L and Glu-73 in GEWL). As an example of the wide variability among the lysozymes, HEWL has a necessary Asp-52 residue, which does not correspond to Asp-20 of T4L, while GEWL has no equivalent for this acidic residue (Kuroki et al., 1999). 


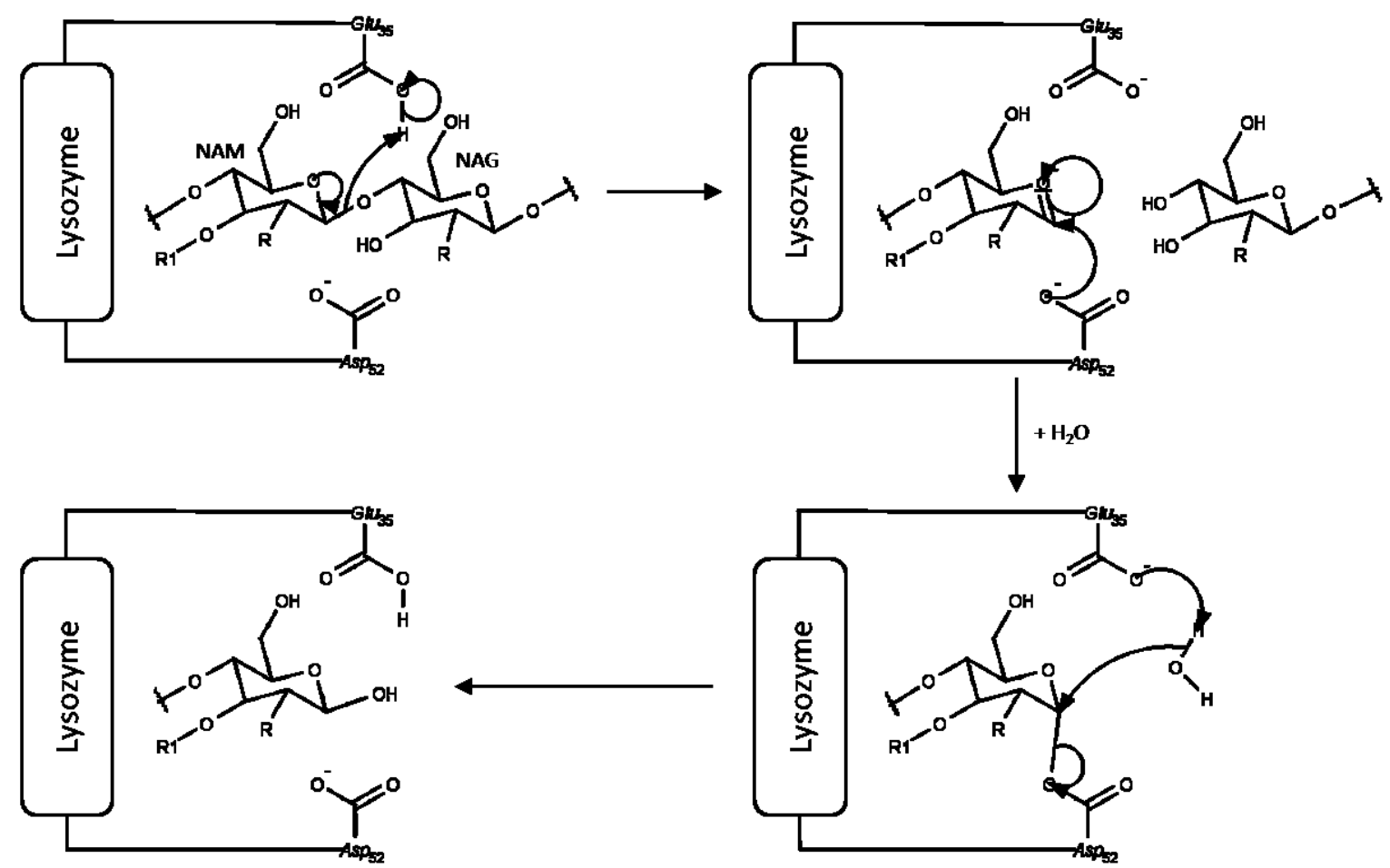

Figure 3. Chemical mechanism for enzymatic breakdown of a peptidoglycan monomer. $\mathrm{R}$ units denote the $\mathrm{N}$-acetyl group and R1 denotes the tetrapeptide side chain to NAM outlined in Figure 2. This has been simplified to improve the clarity of the figure. This figure was sketched using MarvinSketch, a free program used for chemical sketching (http://www.chemaxon.com/products/marvin/marvinsketch/)

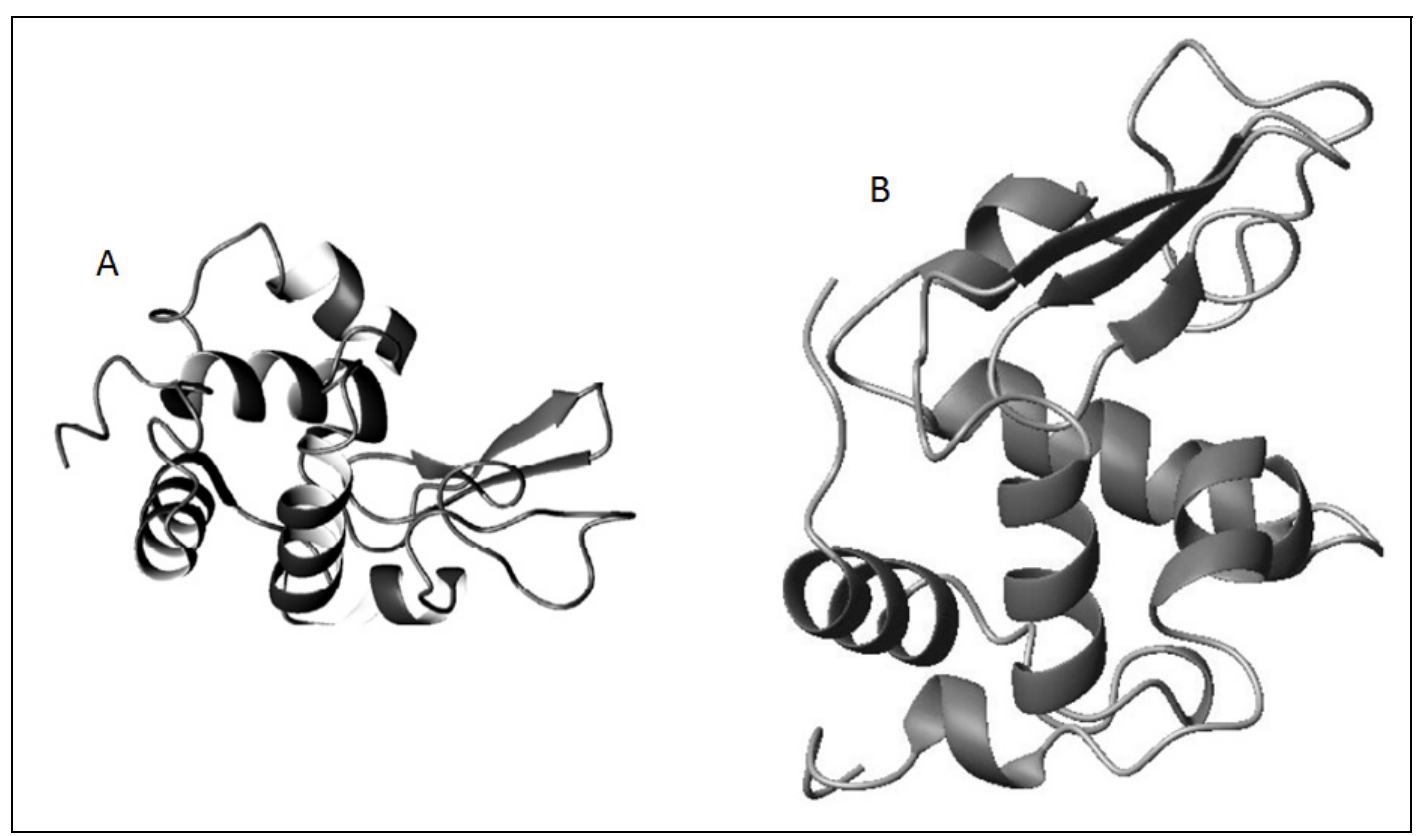

Figure 4. A ribbon model presenting (A) hen egg white lysozyme (HEWL) and (B) bovine milk lysozyme. The differences in structure among the two types of lysozymes are evident. Figure adapted from (Benkerroum, 2008)

\subsection{Lysozyme from Different Species}

While lysozyme is widely distributed in prokaryotes and eukaryotes, it maintains a consistent catalytic function even when grouped into various types based on its amino acid sequence, protein structure and catalytic characteristics (Akinalp et al., 2007; Dong et al., 2008). These types, or classes, are classified by lysozyme's wide 
variability in origin, structural, antigenic, chemical and enzymatic properties. The chicken-type (i.e. c-lysozyme), derived from the egg white of a domestic chicken (Gallus gallus), is the most studied and best known. Although c-lysozyme is typically found in the egg white of birds, it is also purified from various tissues and secretions of mammals. Other types of commonly studied lysozyme include the g-type, derived from the egg white of the domestic goose (Anser anser); h-type lysozyme from plants; i-type from invertebrates; b-type from bacteria (Bacillus); and v-type from viruses (Benkerroum, 2008).

Fleming (1922) showed that lysozyme from different sources affect different organisms: Pneumococcus was attacked only by the lysozyme of pus and Streptococcus haemolyticus only by the lysozyme of tears; Staphylococcus and Streptococcus viridans were more strongly affected by the lysozyme of nasal mucus than by that of tears or pus. Nevertheless, other researchers who worked with egg white lysozyme (which may act differently from lysozyme derived from body tissues) found that none of many Staphylococcus albus and Staphylococcus aureus strains tested, showed marked susceptibility to the lytic action of the lysozyme (Daly, 1938).

\subsubsection{T4 Lysozyme}

Phage T4 is a bacterial virus that infects only bacteria; specifically, it invades and controls bacterial metabolism, then terminates its incubation by lysing the infected-bacterial cell wall using T4L (Sulakvelidze et al., 2001; Trun \& Trempy, 2004). T4L is similar to Hen Egg White Lysozyme (HEWL) in the structure of its active sites and sites of attack on the PG cell wall. Surprisingly, T4L lyses T4-infected cells by attacking the cell wall from the cytoplasmic side (Akinalp et al., 2007). In other words, it can have active sites on both sides of the bacterial cell wall. T4L is a small, well-characterized protein with a molecular weight of approximately $18 \mathrm{kDa}$ and dimensions of 5.4 × $2.8 \times 2.4 \mathrm{~nm}$ (Bower et al., 1998). It is a single polypeptide chain whose entire amino acid composition has been determined; it has a single $\mathrm{NH}_{2}$-terminal methionine residue and a single $\mathrm{COOH}$-terminal leucine residue (Tsugita et al., 1968).

Systematic probing of the T4L structure has also shown that 74 of the 164 positions in its sequence are sensitive to single amino acid substitutions. That is, at least one single amino acid substitution at one of these positions results in at least a 50-fold reduction in function. Not surprisingly, the most critical amino acid residues in the protein have been found to be buried or solvent-exposed in the active site cleft (Poteete et al., 1997).

Although lysozymes from T4 phage and hen egg whites have similar catalytic activity, they have non-homologous amino acid sequences. A comparison of the 3D structure of the phage enzyme with that of hen egg whites has been determined in other studies. The 3D structures of HEWL and T4L have also been seen to be quite different (Matthews \& Remington, 1974); it is not clear whether their respective mechanisms of catalysis are related.

\subsubsection{Hen Egg White Lysozyme (HEWL)}

Lysozyme enzyme isolated from hen egg white is used extensively as a model in protein chemistry, enzymology, protein crystallography, molecular biology and genetics, immunology and evolution. The progress made by the study of these different aspects has been reviewed (Van Dael, 1998). However, HEWL remains, by far, the richest source of lysozyme, with a concentration that ranges between 3400 and $5840 \mathrm{mg} / \mathrm{l}$ (Benkerroum, 2008). HEWL is a 14,600 Da large monomeric protein that consists of 129 amino acid residues. It has been classified as a "hard" protein because the adsorption of HEWL to solid surfaces does not involve any major conformational changes (Malmsten, 2003).

\subsubsection{Human Lysozyme}

Lysozyme has also been identified in numerous human exocrine secretions such as gastroduodenal, genito-urinary, middle ear, salivary, lacrimal, upper and lower airway secretions and in colostrum (Hinnrasky et al., 1990). This enzyme is also found in a wide variety of body fluids, such as respiratory secretions and in cells of the innate immune system, including neutrophils, monocytes, macrophages and epithelial cells (Le Jeune et al., 2010).

Human lysozyme is a key component of the innate immune system and the production of recombinant forms of the enzyme could be promising in the search for therapeutic agents against drug-resistant infections. In addition to its catalytic hydrolysis of cell wall PG, human lysozyme also exhibits catalysis-independent antimicrobial properties. The dual functionality results in a protein that attacks Gram-positive and Gram-negative bacterial pathogens; it has been shown to be the most effective cationic anti-pseudomonal agent in human airway fluids (Gill et al., 2011). Lysozyme has also been found in high concentrations in human airway secretions collected from patients with chronic pulmonary diseases (Hinnrasky et al., 1990). In addition, human colon adenocarcinoma cells synthesize and secrete several specific proteins, including remarkably large amounts of lysozyme. The lack of diagnostic or prognostic markers, as well as the refractory nature of human colon carcinoma to standard chemoimmuno- and 
radio-therapy, makes this an extremely relevant system when investigating the chemistry and biology of such secreted macromolecules (Fett et al., 1985).

Human lysozyme is single polypeptide chain with a low molecular weight of around $14.6 \mathrm{kDa}$ (Cabellero et al., 1999). Human lysozyme is present in the lysosomes of phagocytic cells, granulocytes and monocytes (Burgess et al., 1994). It is released as part of the non-specific immune response and exists among cells of the blood, especially leukocytes. Lysozyme is found in all stages of the maturation of the myelocytic series, but not in the myeloblast, eosinophil or basophil series (Davis, 1971). Monocytes contain large amounts of lysozyme, yet none are found in the lymphocytes. Moreover, in tissues, lysozyme is mainly found in bone marrow, lungs, intestines, spleen and kidneys. Lysozyme exists here due to the breakdown of neutrophilic granulocytes in these organs (Hansen et al., 1972). Tissue macrophages release lysozyme into serum, nasal and lacrimal secretions.

\subsubsection{Lysozyme in Other Vertebrates}

In higher vertebrates, lysozymes are involved in a broad battery of defense mechanisms and embrace several actions such as opsonization, immune response potentiation, restricted anti-viral and antineoplastic activities. Moreover, several studies have indicated that lysozyme may play a role as a defense mechanism against infectious disease in fish (Lie et al., 1989). In addition to their defensive role, lysozymes also play a role in digestive tasks; a dominant gene for high lysozyme activity has been detected in cattle (Lie et al., 1989). Also, high levels of intestinal lysozyme occur in some species of house mice in which the enzyme may play a digestive role. This trait appears in only one of two closely related lysozyme genes in the mouse genome; a Paneth cell (lysozyme P) and a macrophage-specific (lysozyme M) gene (Markart et al., 2004). This resulted in a specific over-expression of lysozyme $\mathrm{P}$ in the small intestine but a normal expression of lysozyme $\mathrm{M}$ in other tissues (Cross et al., 1988).

Furthermore, the milk of virtually all mammals contains lysozyme, either as a free soluble protein or within leucocytes and lysosomes. Although all lysozyme from milk has been reported as belonging to the c-type, it varies widely in terms of structure and physicochemical properties; this includes the folding and unfolding status, ability to bind calcium ions, stability to heat or $\mathrm{pH}$ and isoelectric point (Table 1). In regards to milk lysozyme content, human, equine and canine milks are the main representatives of high levels of lysozyme (averages of 200 to 1330 $\mathrm{mg} / \mathrm{L}$ ), while bovine, ovine and caprine milks (Table 2) represent low levels of lysozyme (3000 to 6000 times less than the milks of the first group) (Benkerroum, 2008). Additionally, the concentration of soluble lysozyme in milk varies considerably from one species to another, as well as within the same species, depending on various factors such as the breed, stage of lactation, parturition, nutrition, udder health and season of the year.

Table 1. Main chemical properties of milk lysozymes of different mammals: chicken egg-white lysozyme properties are also given as a reference for the c-type lysozyme (Benkerroum, 2008)

\begin{tabular}{llll}
\hline \multicolumn{1}{c}{ Origin } & MW $(\mathrm{kDa})$ & Catalytic center residues & \multicolumn{1}{c}{ Reference } \\
\hline Camel milk & 14.4 & NA & El Agamy et al. (1996) \\
Cow milk & 14.4 & Glu $_{35}$ Asp $_{53}$ & El Agamy et al. (2000) \\
Ewe milk & 16.2 & Glu $_{53}$ Asp $_{21}$ & Maroni et Cuccuri (2001) \\
Human & 15 & --- & Parry et al. (1960) \\
Goat & 14.4 & Glu $_{35}$ Asp $_{53}$ & Jolles et al. (1990) \\
Buffalo & 16.0 & NA & El Agamy (2000) \\
Mare & 14.7 & Glu $_{35}$ Asp $_{53}$ & Jauregui-adell (1974); Sarwar et al. (2001) \\
Canine & 14.5 & Glu $_{35}$ Asp $_{53}$ & Grobler et al. (1994) \\
Egg-white & 14.3 & Glu $_{35}$ Asp $_{52}$ & Matagne and Dobson (1998) \\
\hline
\end{tabular}


Table 2. Reported concentrations (mg/L) of lysozyme in the milk of different mammals (Benkerroum, 2008)

\begin{tabular}{lll}
\hline Animal Species & Average concentration & \multicolumn{1}{c}{ References } \\
\hline Human & 400 & Mathur et al. (1990) \\
& 320 & Montagne et al. (1998) \\
& $270-890$ & Montagne et al. (2001) and Chandan et al. (1968) \\
& $224-426$ & Hennart et al. (2004) \\
Ass & 1428 & Salimei et al. (2004) \\
Mare & 790 & Jauregui-Adell (1975) \\
& 1330 & Sarwar et al. (2001) \\
Cow & 0.13 & Chandan et al. (1968) \\
& 0.07 & El Agamy et al. (1996) \\
& $0.05-0.21$ & Piccinni et al. (2005) \\
Buffalo & 0.0012 & Priyadarshini and Kansal (2003) \\
Ewe & 0.1 & Chandan et al. (1968) \\
Goat & 0.25 & Chandan et al. (1968) \\
Sow & 6.8 & Schultz and Müller (1980) \\
Camel & 0.15 & El Agmay et al. (1996) \\
\hline
\end{tabular}

\subsection{Bioengineering and Protein Modifications}

The gene encoding lysozyme was cloned from mammalian tissues and secretions, insects, plants, protozoa, bacteria and viruses, then expressed in bacteria, fungi, yeast and plants (Akinalp et al., 2007). For example, T4L is one of the most thoroughly characterized enzymes through site-specific mutagenesis; more than 2,000 single-amino acid substitutions have been done (Malmsten, 2003). Studies using T4L variants, which differed from each other by at least one amino acid residue provided data that clearly showed a change in enzyme structure (Bower et al., 1998). Numerous variants of T4L have also been produced through site-directed mutagenesis, including a set of variants that differ by substitution of the isoleucine residue at position 3 (Ile 3). Producing variants help to test various physiological characteristics of T4L and the importance of various amino acids in regards to their input on overall protein structure and function. Since the Ile 3 residue contributes to a major hydrophobic core of T4L, any substitution can significantly alter the enzyme's stability (Bower et al., 1998). Notably, when Ile 3 is replaced by Cysteine (Cys) an increase in thermal stability is observed due to the formation of a disulphide bond with another Cys residue at position 97. Thermal unfolding of this mutant revealed that the disulphide bond stabilized the mutant by $1.2 \mathrm{kcal} / \mathrm{mol}$ compared to the wild-type. However, in another mutant, Ile 3 was replaced by the larger amino acid Tryptophan (Trp). This decreased the thermal stability of this mutant by $2.8 \mathrm{kcal} / \mathrm{mol}$ relative to the wild-type, one of the least stable T4L mutants characterized (Malmsten, 2003). Therefore, Ile 3 contributes to the major hydrophobic core of the C-terminal domain and helps link the $\mathrm{N}$ - and C-terminal domains.

In other studies, researchers examined the structure of a mutant $\mathrm{T} 4 \mathrm{~L}$ with a single amino acid substitution $2.5 \mathrm{~nm}$ from the active site. To put this in perspective, lysozyme dimensions are $3.0 \mathrm{~nm}$ x $3.0 \mathrm{~nm}$ x $4.5 \mathrm{~nm}$ (Kim et al., 2002). The change (replacement of glutamate- 128 by a lysine residue) caused very little change in the structure of the lysozyme molecule. Nonetheless the enzyme had only $4 \%$ of the native enzyme's catalytic activity. These results suggest that glutamate-128 participates directly in substrate binding or catalysis. The glutamate residue is located on the $C$-terminal domain, an area that has no counterpart in the HEWL molecule. Therefore, it has been suggested that the role of this $C$-terminal domain is to bind the peptide crosslink that connects neighboring saccharide strands in the E. coli cell wall (Grutter \& Matthews, 1982).

Generally, a major goal of protein engineering is to design proteins that demonstrate enhanced stability and activity. Among the physical forces that maintain the tertiary structure of proteins, disulphide bonds make a substantial contribution. However, the addition of new disulphides has not always increased stability. One aspect of this problem is the limited knowledge of the mechanism for which crosslinks such as disulphide bonds, stabilize or destabilize proteins (Mastsumura et al., 1989). 
The main purposes for early structural studies of lysozyme were to screen for temperature-sensitive (TS) mutants; these studies did not have the benefit of site-directed mutagenesis as methods to generate specific substitutions had not yet been developed. As a result, classical protein chemistry had to be used to determine any sequence changes in TS lysozymes, rather than methods involving DNA sequencing. Nonetheless, five TS T4Ls were developed that reduced the protein's melting temperature by an average of $10^{\circ} \mathrm{C}$. These mutants included the single amino acid changes: Arg $96 \rightarrow$ His $(\mathrm{R} 96 \mathrm{H})$, Met $102 \rightarrow$ Thr (M102T), Ala $146 \rightarrow$ Thr (A146T), Gly $156 \rightarrow$ Asp (G156D), and Thr $157 \rightarrow$ Ile (T157I) (Baase et al., 2010). In a similar study, a multiple mutant was engineered from T4L: I3L/S38D/A41V/A82P/N116D/V131A/N144D (PDB Code 189L) and was shown to increase $T_{m}$ by $8.3^{\circ} \mathrm{C}$ (Zhang et al., 1995).

Currently, entropic effects, hydrophobic stabilization, helical propensity, salt-bridge interactions, metal binding, disulphide bridges, methionine replacement, computational procedures and genetic selection methods are used to generate TS T4Ls. Disulphide bridges are particularly effective at increasing the stability of the protein; for example the formation of a Cys 21-Cys 142 bridge across the active site cleft increases melting temperature by $11^{\circ} \mathrm{C}$ at $\mathrm{pH} 2$ because the protein bends to accommodate the disulphide bond (Baase et al., 2010). Furthermore, the genetics of T4L have been studied extensively and a variety of mutant enzymes have been isolated and characterized. A previous study suggested that the residues Asp 20, Glu 22, Glu 105, Trp 138, Asn 140 and Glu 141 are all essential for full catalytic activity on the grounds that changes in any of these amino acids drastically reduce the catalytic effectiveness of the enzyme (Matthews \& Remington, 1974).

In contrast, the close proximity of the substituted residue Ile 3 to the active site Glu 11 may also contribute to the observed differences in activity among T4L variants because both residues are located on the same $\alpha$-helix. The $\alpha$-helix content of a protein in a solution is known to increase or decrease in response to changes in its environment (e.g., $\mathrm{pH}$, ionic strength and hydrophobic nature of the solvent). A T4L variant containing a relatively large tryptophan residue in position 3 could make conformational changes in adjacent residues. If these effects are propagated along the $\alpha$-helix, significant changes in the orientation of the active site may result in a decrease in catalytic activity (Bower et al., 1998).

Moreover, the loss of catalytic activity of the T4L variants might also relate to the degree of interference caused by mutation in the hinge region of the enzyme. These amino acid substitutions are located directly opposite the active site in an area of the molecule that is responsible for the opening and closing movement of the active cleft. As such, an enzyme would retain full activity only if the substrate were able to force its way past the "hinged" cleft to reach the active site (Bower et al., 1998).

\section{Lysozyme Applications}

\subsection{Diagnostic Applications}

Lysozyme has been shown to be an indicator in some hematological malignancy; such as acute myeloid leukemia. In addition, an elevated serum lysozyme level could be helpful in differentiating between the types of cancer that affect blood, bone marrow and lymph nodes. However, lysozyme has been associated with other abnormalities since its activity increases in the gastric juice of patients with a peptic ulcer and in the colonic sections of patients with ulcerative colitis and regional enteritis (Mir, 1977). Elevated levels of lysozyme are also associated with certain abnormalities in humans. Deviations in lysozyme levels of blood and urine have been correlated to particular myeloid and renal abnormalities and lysozyme levels have subsequently been used to monitor the success of therapy. Although the lysozyme protein can be found in most tissues, studies at the cellular level have revealed that it is present in high concentrations, specifically in phagocytic cells and the Paneth cells (including the intestine and the proximal tubules of the kidney). While the kidney accumulates at least some of its lysozyme from the blood, endogenous lysozyme synthesis has been detected in mammalian myeloid cells (Cross et al., 1988). Additionally, lysozymuria has been reported in various renal tubular disorders as a manifestation of the disease. Furthermore, discrepancies could be caused by differences in methods, patient populations and stages of disease (Mir, 1977). It was also reported that lysozyme is an effective agent for killing HIV in vitro (Song \& Hou, 2003)

\subsection{Industrial Applications of Lysozyme}

Lysozyme is gaining importance for its biotechnological applications; particularly in agriculture to control plant pathogens. It has also been used in food preservation due to its antibacterial activity. The success in employing lysozyme for different industrial applications depends on the supply of highly active preparations at a reasonable cost (Patil et al., 2000). Although egg white is the primary source for lysozyme production on an industrial scale, other sources such as mammals' milk contain lysozyme molecules with specific properties that are not present in the conventional egg white lysozyme (Benkerroum, 2008). 
Chicken egg white lysozyme has also been recently used in some oenology processes (e.g. wine maturation) at a level of $100 \mathrm{mg} / \mathrm{L}$ to control contamination by lactic bacteria (Benkerroum, 2008; Ferreira et al., 2011). Furthermore, from a biochemical perspective, lysozyme has an optimum activity between $40^{\circ} \mathrm{C}$ and $45^{\circ} \mathrm{C}$ and can remain active up to $62^{\circ} \mathrm{C}$, which is compatible with the temperature used for enzymatic hydrolysis. Also, enzymatic activity is effective within a pH value range between 3.5 and 7; however, it can remain active between pH 2 and 10 (Ferreira et al., 2011).

The use of lysozyme can reduce the use of sulfur dioxide $\left(\mathrm{SO}_{2}\right)$ to limit microbial contamination in many industrial processes. However, this usage is expensive and has health-related side effects (Ferreira et al., 2011).

\subsubsection{Lysozyme in Food Packaging}

Antimicrobial packaging is a form of active packaging because it has the ability to kill or inhibit spoilage by pathogenic microorganisms that contaminate foods unlike conventional packaging systems that only increase shelf-life (Han, 2000). Table 3 shows the application area when lysozyme is used as an antimicrobial agent and when packaging materials are used in antimicrobial food packaging. Several studies have shown that incorporating lysozyme as a preservative in packaging materials extends the shelf life of foods (Appendini \& Hotchkiss, 1997; Buonocore et al., 2004; Mecitoglu et al., 2006).

Table 3. Application area, antimicrobial agents and packaging materials used in antimicrobial food packaging (Han 2000; Appendini \& Hotchkiss, 2002)

\begin{tabular}{lll}
\hline Antimicrobial Agent & Packaging Material & Application area \\
\hline Lysozyme & LDPE* & Bell pepper \\
& LDPE & Cheese \\
\hline
\end{tabular}

* LDPE: low-density polyethylene.

Food-borne microbial outbreaks have garnered much of the media's attention and as such have sparked a greater interest in antimicrobial food packaging. Antimicrobial agents may be mixed with the initial food formulations, or they may be applied to food surfaces by dusting, dipping or spraying (Min \& Krochta, 2005). However, the antimicrobial agents may be neutralized in reactions within the food system, diminishing their protective abilities. Furthermore, antimicrobial agents within the food are unable to target food surfaces, where spoilage reactions take place most intensely. Antimicrobial packaging allows for a slow release of antimicrobial agent from the film onto the surface of the food, allowing for the maintenance of the concentration needed for the inhibition of microbial growth (De Roever, 1998; Devlieghere et al., 2004).

Typically, antimicrobial films are produced with organic or inorganic acids, metals, alcohols, ammonium compounds or amines (Appendini \& Hotchkiss, 2002; Suppakul et al., 2003). However, natural bio-preservatives such as antimicrobial enzymes and bacteriocins have gained much interest due to a growing concern for healthy foods (Suppakul et al., 2003; Labuza \& Breene, 1989). Naturally, lysozyme has become one of the most studied bio-preservatives for antimicrobial packaging applications (Han, 2000; Quintavalla \& Vicini, 2002).

There is also interest in increasing the antimicrobial spectrum of lysozyme. For instance, the combination of lysozyme with EDTA makes lysozyme highly effective on Gram-negative bacteria (Mecitoglu et al., 2006), and conjugates of lysozyme with dextran, galactomannan or xyloglucan have good antimicrobial activity against both Gram-positive and Gram-negative bacteria when applied in combination with mild heating at $50^{\circ} \mathrm{C}$ (Nakamura et al., 1992).

\subsubsection{Resistance to Lysozyme by Gram Positive/Negative Bacteria}

While PG in Gram-positive bacteria cell walls is freely accessible to lysozyme, PG in Gram-negative bacteria is shielded by the lipopolysaccharidic (LPS) layer of the outer membrane. In addition to this protective effect against the hydrolytic action of lysozyme, Gram-negative bacteria have recently been shown to use another strategy that involves specific protein-inhibitors with high affinity to lysozyme (Benkerroum, 2008). Bacterial resistance to lysozyme is not exclusively related to the presence of the LPS layer because it does not provide absolute protection against the hydrolytic action of lysozyme. Sensitive Gram-negative bacteria have been described, along with mechanisms not hindered by LPS.

Specifically, Fleming and Allison (1927) were the first to report resistant strains of Streptococcus. They found that lysozyme was not effective against a range of bacteria that included Haemophilus influenzae, Neisseria 
meningitidis, Escherichia coli, Streptococcus pneumonia (Gram-positive), Klebsiella pneumoniae and group B Streptococci (Gram-positive). They then characterized lysozyme resistance as an inability to break down bacteria that are encapsulated with a gelatinous polysaccharide layer. This dramatically limits the effectiveness of lysozyme to bacteria that have no capsule. Lysozyme is therefore of little value as a therapeutic agent against bacterial growth, but the release of lysozyme as a product of phagocytosis and white blood cell turnover may be a useful marker for sepsis.

\subsubsection{Mechanism of Resistance to Lysozyme}

The complexity of the composition and structure of peptidoglycan is well known (Le Jeune et al., 2010). Its pathological effects are greatly enhanced by various modifications and substitutions to its basic composition and structure (Clarke \& Dupont, 1992). While some bacterial species are sensitive to lysozyme, many bacteria (like some important human pathogens such as Staphylococcus aureus, Neisseria gonorrhoeae, Enterococcus faecalis and Proteus mirabilis) are resistant to lysozyme (Le Jeune et al., 2010; Herbert et al., 2007).

The exact mechanism of lysozyme resistance is not fully understood and may vary according to the bacterial strain or species (Benkerroum, 2008). One mechanism of resistance that has been suggested is interference of lysozyme action by surface attachment polymers (e.g., capsular polysaccharides and teichoic acids) (Benkerroum, 2008). For example, a high degree of peptide cross-linkage can add positively charged residues to teichoic and lipoteichoic acids, thereby modifying the net negative charge on the bacterial cell surface (Bera et al., 2005; Herbert et al., 2007; Benkerroum, 2008). This modification helps the bacteria to avoid the CAMP activity of lysozyme and disrupts many other antimicrobial peptides (Herbert et al., 2007; Le Jeune et al., 2010). In most cases, these peptide side chains are involved in the direct cross-linking between adjacent glycan strands; however, in some instances, a more complicated arrangement exists. For example, a pentaglycine peptide bridges the neighbouring peptide side chains within the peptidoglycan sacculus of Staphylococcus aureus (Clarke \& Dupont, 1992); this is a modification of different sites of the PG structure by a type of enzyme (e.g., the peptidoglycan-specific $O$-acetyltransferase (OatA) of $S$. aureus) (Le Jeune et al., 2010). Similarly, this has been reported for 11 Gram-positive and Gram-negative species (Bera et al., 2005), which results in $O$-acetylation of hexosamine residues of the cell wall PG (Benkerroum, 2008) and the N-acetylglucosamine deacetylase $(P g d A)$ of Streptococcus pneumonia. Both prevent the binding of lysozyme to its substrate and contribute to the muramidase resistance. $\mathrm{N}$-deacetylation of the acetamido group of the hexosamine residues (Benkerroum, 2008), incorporation of D-Aspartic acid in the bacterial PG cross bridge, as was demonstrated in Lactococcus lactis, and the production of protein-inhibitors specific to lysozyme, $N$-non-substituted glucosamine residues in the peptidoglycan, as in Bacillus cereus and Streptococcus pneumonia (Bera et al., 2005). Lysozyme resistance may also consist of the production of lysozyme inhibitors such as the Streptococcal Inhibitor of Complement (SIC) in streptococci; the inhibitor of vertebrate lysozyme in E. coli; the Periplasmic Lysozyme Inhibitor of c-type lysozyme in Salmonella enteritidis; or the Membrane-bound Lysozyme Inhibitor of c-type lysozyme in E. coli (Le Jeune et al., 2010).

Over recent years, these mechanisms have been gaining attention. While there is a general agreement that surface attachment polymers and the degree of peptide cross-linking do not account for lysozyme-resistance, it is not clear whether there is only a single mechanism of resistance for all bacteria or if specific mechanisms may be used by specific strains or species. However, the above mechanisms may be modulated by other factors that are not directly involved in lysozyme resistance. For example, the presence of teichoic acid or a high degree of peptide cross-linking, though shown not to have an intrinsic effect on lysozyme resistance, has significantly enhanced the effect of $O$-acetylation on lysozyme resistance in $S$. aureus (Benkerroum, 2008). For example, some species of eubacteria known to possess $O$-acetylated peptidoglycan like Neisseria gonorrhoeae, Proteus mirabilis and Staphylococcus aureus have the presence of acetyl moieties at the C-6 hydroxyl group of $N$-acetylmuramyl residues (Clarke \& Dupont, 1992). $O$-acetylation of peptidoglycan produces corresponding 2,6-diacetylmuramyl derivatives. The extent of naturally occurring $O$-acetylation in microorganisms ranges between $<10 \%$ and $70 \%$, while a spontaneous mutant of Micrococcus luteus, cultured in the presence of HEWL, has been reported to have a molar ratio of 1:1 for $N$-acetylmuramic acid and $O$-acetyl. The role of $O$-acetylation in conferring resistance to the hydrolytic activity of HEWL was discerned soon after the initial discovery of the modification. Subsequent studies have confirmed the resistance of $O$-acetylated peptidoglycan to lysozyme; however, it should be noted that the efficacy of others, such as the N,O-diacetylmuramidases of Chalaropsis and Streptomyces globisporus is not affected by O-acetyl groups (Clarke \& Dupont, 1992).

Moreover, as with other types of modifications to peptidoglycan, the chloramphenicol-induced increase in the degree of 6-O-acetylation of the $\mathrm{N}$. gonorrhoeae $\mathrm{PG}$ was observed to immediately follow the cessation of protein synthesis; this subsequent acetylation was limited to newly incorporated PG. Therefore, while the process of $O$-acetylation occurs outside the cytoplasm, it would appear that it is regulated by agents that act directly on 
cytoplasmic targets. Of therapeutic concern, the increased 6-O-acetyl content of cell walls in bacteria that are treated with this antibiotic serve to increase its resistance to lysozyme (Clarke \& Dupont, 1992).

To overcome the bactericidal action of lysozyme, bacteria have developed different mechanisms, among which some have been well dissected. Further, these are mainly based on the modification of the PG structure (Le Jeune et al., 2010). There is still a need for further investigation to explore mechanisms of lysozyme resistance to improve the use of lysozyme in therapeutics.

\subsubsection{Inhibitory Activity of Lysozyme against Microorganisms Other than Bacteria}

To date, no clear explanation has been provided for the sensitivity of some viruses to lysozyme. However, it was suggested that the inhibition of the herpes virus is due to interference with antiviral activity because of the basic nature of lysozyme, rather than the hydrolytic activity (Cisani et al., 1984). Moreover, in vitro inhibition of human immunodeficiency virus (HIV) by lysozyme was attributed to the hydrolysis of viral polysaccharides and genomic RNA (Benkerroum, 2008). Therefore, lysozyme may not always act by its hydrolytic activity, but it could inhibit the growth of some microorganisms either by permeabilizing the plasma membrane or acting on intracellular components by virtue of its cationic hydrophobic nature, as has been described for a variety of antimicrobial peptides. Sublethal concentrations $(10 \mu \mathrm{g} / \mathrm{ml})$ of lysozyme were shown to accumulate in the cytoplasm of Candida albicans and reduce the production and activity of aspartic proteinase, a putative virulence factor of yeast. This finding indicates that lysozyme acts at the transcriptional or translational level of DNA expression and, while at high concentrations, induces cell-swelling and invaginations near bud scars. This suggests that interference with the synthesis of cell-wall components may be alternative targets for this enzyme (Benkerroum, 2008).

Several factors that influence lytic efficiency have been discussed in other studies. Specifically, increases in the amount of lysozyme used were not particularly effective in increasing extent of lysis, but it was found that lysis improved with the lengthening of the incubation period. Another factor that is likely to produce a large change in lytic efficiency is the growth medium. It was found that supplementation of the growth medium with L-threonine, L-lysine or both, usually produced streptococci or lactobacilli cells that were lysed more easily. The action of threonine can be explained by its known interference in the establishment of cell wall cross-links. The mode of action of L-lysine is more difficult to explain, but it is obvious that the composition of the growth medium can affect the susceptibility of bacteria to lysozyme; therefore, it should be evaluated with strains that are difficult to lyse (Chassy \& Giuffrida, 1980). In addition, the choice of buffers could be a major factor in determining the efficiency of lysozyme. Other studies have used high $\mathrm{pH}$ values, high buffer concentrations or phosphate buffers. Thus, the use of $\mathrm{NaCl}, \mathrm{MgCl}_{2}$, other salts or chelating anions should be avoided because these additives appear to interfere with lysis of Gram-positive, asporogenous bacteria. Finally, another factor that contributes to its effectiveness is the enzymatic stabilizer polyethylene glycol (PEG), which appears to act as a stimulant of lysis rather than an osmotic stabilizer (Chassy \& Giuffrida, 1980).

\section{Lysozyme Detection}

Numerous methods have been reported for the detection of lysozyme and the determination of its concentration. A method was reported in 1946 in which an Ostwald or Uberlohde's viscometer was employed in the determination of lysozyme by monitoring the decrease in viscosity of various substrates (Song \& Hou, 2003). Until now, the most widely used method was chromatography involving HPLC and affinity chromatography. Furthermore, a nephelometric immunoassay has also been developed and has a detection limit of $0.58 \mathrm{mg} / \mathrm{ml}$ for assay of lysozyme. Several other useful methods have been proposed, including response surface methodology and fluorimetry and acoustic wave viscosity sensing (Song \& Hou, 2003).

\subsection{Agar Plate Bioassays}

The lysoplate method has been used as the basis for assay development because it showed that lysozyme was able to diffuse through the agar and prevent growth of the bacteria (Fleming \& Allison, 1922). In another experiment, agar was mixed with heat inactivated bacteria so that it appeared turbid. The agar was allowed to solidify and then wells were bored into it. Lysozyme samples were added to these wells and allowed to diffuse over 12-18 hours. Then the zone of turbidity clearing was observed to determine the proportional concentration of lysozyme (Osserman \& Lawlor, 1966). Similarly, the measurement of lysozyme activity by agar plate bioassay with Micrococcus luteus cells as a test strain is an indicator test. Enzyme-action produces a clear zone of inhibition of M. luteus with diameters that are proportional to the catalytic activity of the enzyme (Bower, Xuand and McGuire, 1998). Therefore, the use of agar plate bioassays is a quick, simple and efficient method for determining lysozyme activity. 


\subsection{Activity in Media Measurements (Turbidimetric)}

Many of the turbidimetric methods used to measure the activity of lysozyme are similar and differ only with respect to the lysozyme activity and sample preparation. These differences might include buffer composition, $\mathrm{pH}$, ionic strength, concentration of $M$. luteus substrate, temperature, duration of incubation and preparation of enzyme (Houser, 1983). An example of this method involves dissolving M. luteus cells in phosphate buffer (e.g. $0.01 \mathrm{M}$; $\mathrm{pH} 7.3$ ) to give a stable suspension with an optical density of 0.9 at $450 \mathrm{~nm}$. The activity of the lysozyme sample was determined by the decrease in turbidity of the Micrococcus suspension (at $450 \mathrm{~nm}$ ) using a spectrophotometer. In this method, for each activity assay, $100 \mu \mathrm{l}$ of T4L $(0.5 \mathrm{mg} / \mathrm{ml})$ was added to $3.0 \mathrm{ml}$ of substrate and the decrease in optical density (absorbance) was recorded every $0.1 \mathrm{~s}$ for $60 \mathrm{~s}$ (Bower et al., 1998).

In a review, Klass et al. (1977) described the turbidimetric technique as having a high sensitivity and a rapid turnover rate; each sample took only one minute to process. They developed a method that has a detection limit of $1 \mu \mathrm{g} / \mathrm{ml}$ whereas a method by Ronan et al. (1975) has a detection limit of $1.5 \mathrm{mg} / \mathrm{ml}$. Although the method by Klass et al. (1977) is the preferred method for routine testing of clinical samples because it is time effective, it is not the most reliable method as it produces a high inter-batch variability of results, with a precision of $2.5 \%$ as was obtained by Gorin et al. (1971). Bergmeyer (1965) however achieved a higher rate of precision. Regardless of its unreliability, this assay is easy to perform, requires small sample volumes, can be used with serum, urine and tears and is sensitive (Gorin et al., 1971; Bergmeyer, 1965).

An assay method that involved the use of two colorimeters, which correct the urine and serum discoloration problems experienced with controls (causing turbid solutions for blank samples), was developed. The bacterial suspension and clinical samples were continuously stirred and standards were run simultaneously. This automated assay was able to process 20 samples per hour and had an increased (yet undisclosed) sensitivity (Terry et al., 1971).

Furthermore, another method based on the principles of the turbidimetric assay was devised by Caballero et al. (1999). They described a micro-particle enhanced nephelometric immunoassay using serum and urine samples from patients. This assay involved the use of polystyrene particles covalently bound with anti-lysozyme antibodies. The polystyrene particles formed larger particles due to the binding with free lysozyme in the sample, which resulted in scattered light. The scattered light at the start and end of the reaction was compared and used to calculate the lysozyme concentration in the patient sample. The assay detection limit was $0.58 \mathrm{mg} / \mathrm{L}$. However, this assay involves long incubation periods, requires biological fluid pre-treatment and has poor detection limit (Caballero et al., 1999).

Finally, a commercial assay currently on the market that employs the principle of turbidimetric assays is the EnzChek ${ }^{\circledR}$ Lysozyme by Molecular Probes (Leiden, Netherlands). This test measures lysozyme in solution at levels as low as $20 \mathrm{U} / \mathrm{ml}$ (equivalent to $<0.5 \mu \mathrm{g} / \mathrm{ml}$ ). The lysozyme activity is measured using M. luteus cell walls as substrate. The bacterial cell walls are specially labeled with a fluorophore in such a way that the fluorescence is quenched. Thus, activated lysozyme reduces the quenching while increasing the fluorescence. The fluorescence is therefore proportional to the lysozyme activity. The increase in fluorescence is measured using a spectro-fluorometer, mini fluorometer or a fluorescence microplate reader. Each assay takes around 30 minutes with less than an hour preparation time. The assay lays claim to being "simple and sensitive" (https://tools.invitrogen.com/content/sfs/manuals/mp22013.pdf).

\subsubsection{Thermostability of Lysozyme on SDS-PAGE}

To determine the thermostability of lysozyme enzymes, Akinalp et al. (2007) exposed the supernatant of various recombinant bacteria to various temperatures (from $37^{\circ} \mathrm{C}$ to $100^{\circ} \mathrm{C}$ ) for $15 \mathrm{~min}$ followed by centrifugation at $15,000 \mathrm{rpm}$ to remove denatured proteins. The supernatant was then mixed with an equal volume of trichloroacetic acid and the protein collected by centrifugation. Protein analysis was then performed using a denaturing polyacrylamide gel (SDS-PAGE, $12 \%(\mathrm{w} / \mathrm{v})$ ). After electrophoresis, protein bands were visualized by a coomassie blue staining. As a result, the thermostability of the lysozymes from the recombinant bacteria was found to be different. The lysozyme expressed by $S$. salivarius subsp. thermophilus cells has high thermoresistance and was not denatured at $70^{\circ} \mathrm{C}$ for $15 \mathrm{~min}$. In contrast, the enzyme expressed by L. lactis and E. coli cells was easily denatured when exposed to the same temperature.

\subsection{Immunoassays}

The lack of sensitivity and long assay times of the turbidimetric and lysoplate techniques has led to the development of various immunoassay methods for the determination of lysozymes. Immunoassays rely on the reaction between the target analytic and a specific binding molecule of biological descent (the antibody). They can 
produce both quantitative and qualitative results and have shown considerable improvements in sensitivity (Ekins \& Chu, 1997). For example, Porstmann et al. (1989) developed an enzyme immunoassay for the detection of lysozyme in patients with Crohn's disease and rheumatoid arthritis. Urine samples were taken from patients and were tested using three variations of the same method. The method showing highest sensitivity involved pre-coating a microtitre plate with anti-lysozyme $\operatorname{IgG}$ overnight at $4^{\circ} \mathrm{C}$, followed by two hours incubation at room temperature with the clinical sample and IgG-HRP (Horseradish Peroxidase) conjugate. Then, the assay was stopped by addition of o-henylenediamine with 15 minutes incubation. The detection limit for this assay was 0.2 $\mu \mathrm{g} / \mathrm{L}$ (Porstmann et al., 1989).

Francina et al. (1986) reported an immunoassay developed to test lysozyme secretion in serum of acute myeloid leukemia patients. A microtitre plate was incubated at $4^{\circ} \mathrm{C}$ overnight with anti-lysozyme IgG. After a wash, the plate was incubated for one hour at $37^{\circ} \mathrm{C}$ with the clinical sample then biotinylated antilysozyme was added and the plate was again incubated for a further hour. The plate was then washed and incubated with avidin peroxidase solution for 10 minutes at room temperature. The assay was stopped by the addition of enzyme substrate and incubated for five minutes. The total assay time was $\sim 14.5$ hours. To reduce assay time the two one-hour incubations were reduced to 20 minutes and the enzyme substrate incubation to five minutes. The detection limit for the standard assay was $0.1 \mathrm{ng} / \mathrm{ml}$ and for the rapid assays $1 \mathrm{ng} / \mathrm{ml}$. In another example, Taylor et al. (1992) reported an immunoassay to measure lysozyme in a healthy adult's serum and urine samples. The method involved pre-coating a microtitre plate with rabbit anti-human lysozyme, followed by addition of the clinical sample and incubation for 90 minutes at room temperature. Additionally, a conjugated sheep anti-human lysozyme was added and incubated for a further 90 minutes at room temperature. Finally, enzyme substrate $p$-nitrophenyl sodium phosphate was added and incubated for 30 minutes at room temperature. The total assay time was 15 hours and the detection limit was $1 \mu \mathrm{g} / \mathrm{L}$.

At present, there are some immunoassay kits available on the market and these include the Human Lysozyme EIA kit from Biomedical Technologies Inc. (Stoughton, USA). Referred to as sandwich ELISA, this method detects lysozyme from serum, plasma, urine, tears and saliva; the reference value for human lysozyme from serum ranges from 3-10 $\mu \mathrm{g} / \mathrm{ml}$. In this assay, specific lysozyme antibodies bound to polystyrene wells are incubated with a sample and then a second human lysozyme-specific antibody is added with a horseradish peroxidase conjugated secondary antibody. The total test time is $4 \frac{1}{4}$ hours (http://www.funakoshi.co.jp/data/datasheet/BTI/BT-630.pdf).

Similarly, a company Orgentec (Mainz, Germany) supplies a kit known as Anti-Lysozyme kit for lysozyme in serum and plasma. This test can process 96 patient samples at a time, only requires $10 \mu \mathrm{l}$ of sample and involves a plate pre-coated with antibody. The antigen from the patients' sample is added along with a horseradish peroxidase conjugate and then followed by TMB (a color substrate). The reaction is stopped by adding hydrochloric acid; the total time for this assay is two hours, due to the plates being purchased pre-coated (http://www.orgentec.com/products/pdfs/ELISA_en_IFU_ORG_526.pdf). All of these kits have the advantage of conducting analysis on several patient samples using minimal biological fluid.

\subsection{Biosensor}

Biosensor and related bioarray techniques are rapidly growing fields. A biosensor is an analytical device that converts the concentration of the target substances into an electrical signal via a combination of biological or biologically-derived recognition systems, either integrated within or intimately associated with a suitable physico-chemical transducer. Essentially, biosensors consist of three parts: recognition, transduction and signal output. A biological sensing element coordinated with a transducer will generate a signal that is proportional to the target analyses. An interaction between the biological receptor molecules and the target analyses causes a change in one or more physical or chemical parameters such as the generation of ions, gases, electrons, heat or mass. These changes are interpreted by the transducer and converted into electrical signals (Figure 5).

In addition, biological or biologically-derived elements are capable of recognizing the presence, activity, or concentration of a specific target analyte in a complex mixture of components. The recognition element may comprise one of three different types: affinity biosensors (based on ligand-receptor interactions such as those involving antibodies, nucleic acid, aptamers, peptides, protein or cell receptor); binding and catalysis (involves enzymes, microorganisms, organelles, plant or animal cells or tissue slices); or biomimetic receptors (based on various synthetic binding or catalytic systems). The interaction, or subsequent reaction, of the recognition element with the analyte in a sample matrix results in a reactant or formation of a product that is immediately proximal to the transducer. The latter converts the change in solution property into a quantifiable electrical signal. The transducer is a device, usually electronic, electroacoustic, electro-optical, electromagnetic, electrothermal or electromechanical that converts one type of energy (electricity, sound, light, magnetism, heat or mechanical) into 
another (usually electrical) for various purposes including measurement or information transfer (Marks et al., 2007).

More research is needed to develop an electrochemical approach for the detection of lysozyme; such a biosensor will offer an alternative, sensitive and versatile method for protein detection.

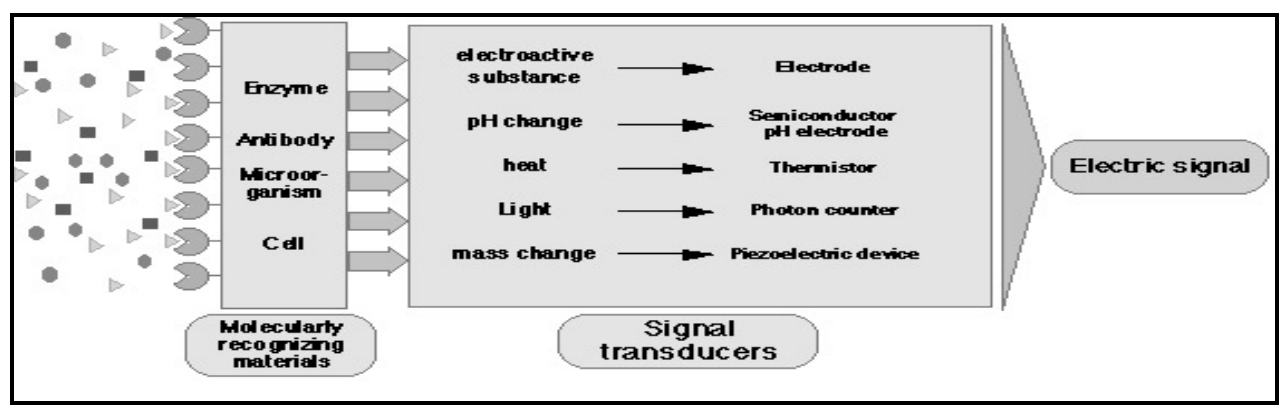

Figure 5. The principle of a biosensor (http://www.jaist.ac.jp/ yokoyama/images/biosensor.gif)

\subsection{Flow Injection Chemiluminescence System}

A new procedure using chemiluminescence (CL) detection has been developed to determine the levels of lysozyme at a ng/ml level. This procedure, termed Flow Injection Chemiluminescence (FICL) uses controlled reagent release technology within a flow injection system where the analytical reagents are immobilized on an anion-exchange resin. Upon injection with water, some of the analytical reagents, like luminol and periodate, are eluted from the column. Initially, CL is inhibited due to the presence of lysozyme, but upon release from the column, these reagents are free to luminesce (Song \& Hou, 2003). The concentration of lysozyme can be calculated within a range of $30-1000 \mathrm{ng} / \mathrm{ml}$ based on the decline in CL intensity (Figure 6). Using this method, a typical analytical procedure could be performed in 0.5 minutes, including sampling and washing, when performed at a flow rate of $2.0 \mathrm{ml} / \mathrm{min}$. This would provide a throughput of $120 \mathrm{ml} / \mathrm{h}$ with a relative standard deviation of less than $3.0 \%$. Song and Hou (2003) successfully applied this method to determine the concentration of lysozyme in human tear and saliva samples with recovery rates from $92.0 \%$ to $105.7 \%$.

Flow Injection Chemiluminescence (FICL) analysis is becoming increasingly important in various fields because of its high sensitivity, rapidity, simplicity and feasibility. The fast oxidation reaction between luminol and periodate in alkaline medium produces a strong CL signal. Furthermore, CL is greatly inhibited by lysozyme, so a sensitive CL inhibition assay for lysozyme combined with FI technology was described (Figure 7). This method offered simple and cheap instrumentation as well as rapid and reproducible means of detection; demonstrated in its application to determine lysozyme in human tear and saliva. Subsequently, a sensitive and convenient analytical method using control-reagent-release technology in a flow injection system was developed to determine lysozyme in human tears and saliva by its inhibitory effect on CL. In addition, incorporation of the immobilized reagents column into the flow injection analysis (FIA) manifold offers satisfactory stability, good reproducibility and precision in the analysis (Song \& Hou, 2003).

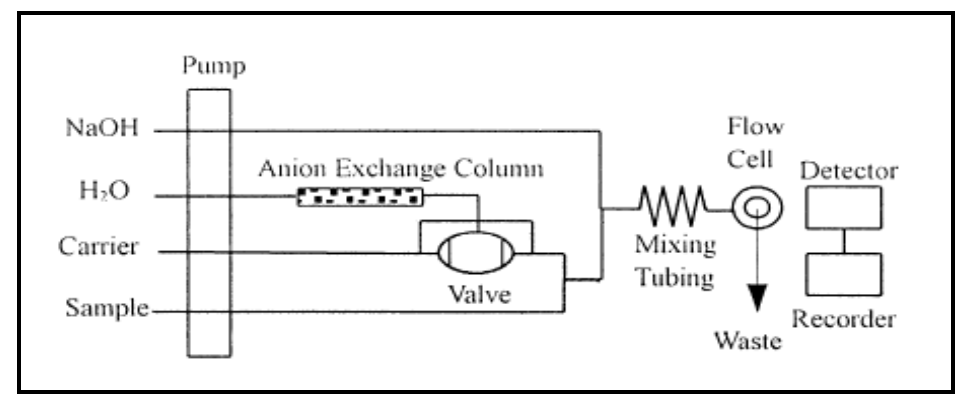

Figure 6. Schematic diagram of the flow-injection system for lysozyme determination (Song \& Hou, 2003) 


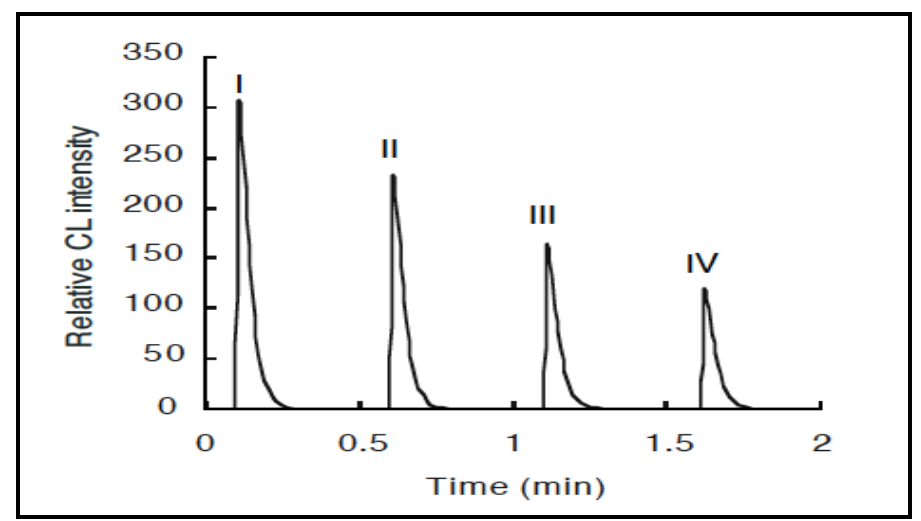

Figure 7. CL time profile in the batch system. I - CL intensity in the absence of lysozyme; II - CL intensity in the presence of lysozyme (50 $\left.\mathrm{ng} \mathrm{ml}^{-1}\right)$; III - CL intensity in the presence of lysozyme (150 $\left.\mathrm{ng} \mathrm{ml}^{-1}\right)$; IV - CL intensity in the presence of lysozyme (500 $\mathrm{ng} \mathrm{ml}^{-1}$ ) (Song \& Hou, 2003)

\section{Conclusion}

This paper has covered multiple facets of lysozyme, including its history, functions and industrial purposes. Mechanisms of resistance were also explored, while protein structure and notable modifications were stressed. Lastly, various methods used in lysozyme detection were presented. Lysozyme is a crucial enzyme in the innate immune system and has many potential industrial uses such as in food processing, packaging and preservation. Studying it would also provide more knowledge about how the body fights infection and other intrusions. Although several sources for lysozyme exist, future studies should be directed to generating a modified structure suitable for large scale production or to produce a recombinant variation. It is also possible to explore other purposes for lysozyme such as biofilm management on varying surfaces, modified chitinase abilities or selective targeting for various specific bacterial peptidoglycans.

\section{References}

Akinalp, A. S., Asan, M., \& Ozcan, N. (2007). Expression of T4 lysozyme gene (gene e) in Streptococcus salivarius subsp. thermophilus. Afr. J. Biotechnol., 6, 963-966.

Alberts, B., Bray, D., Hopkin, K., Johnson, A., Lewis, J., Raff, M., ... Walter, P. (2010). Essential Cell Biology (3rd ed.). London: Taylor and Francis Group.

Appendini, P., \& Hotchkiss, J. H. (1997). Immobilization of lysozyme on food contact polymers as potential antimicrobial films. Packag. Technol Sci., 10, 271-279. http://dx.doi.org/10.1002/(SICI)1099-1522(199709/ 10)10:5<271::AID-PTS412>3.0.CO;2-R

Appendini, P., \& Hotchkiss, J. H. (2002). Review of antimicrobial food packaging. Innov. Food Set Emerg. Technol., 3, 113-126. http://dx.doi.org/10.1016/S1466-8564(02)00012-7

Baase, W. A., Liu, L., Tronrud, D. E., \& Matthews, B. W. (2010). Lessons from the lysozyme of phage T4. Protein Sci, 19(4), 631-641. http://dx.doi.org/10.1002/pro.344

Benkerroum, N. (2008). Antimicrobial activity of lysozyme with special relevance to milk. Afr. J. Biotechnol., 7 , 4856-4867.

Bera, A., Herbert, S., Jakob, A., Vollmer, W., \& Gotz, F. (2005). Why are pathogenic staphylococci so lysozyme resistant? The peptidoglycan O-acetyltransferase OatA is the major determinant for lysozyme resistance of Staphylococcus aureus. Mol Microbiol, 55(3), 778-787. http://dx.doi.org/10.1111/j.1365-2958.2004.04446.x

CCM international limited. (2011). Bio-products: BRI of CAAS awaiting investments in T4 lysozyme industrialization. Industrial Biotechnologies China News, 3(01), 4.

Blake, C. C., Koenig, D. F., Mair, G. A., North, A. C., Phillips, D. C., \& Sarma, V. R. (1965). Structure of hen egg-white lysozyme. A three-dimensional Fourier synthesis at 2 A resolution. Nature, 206(4986), 757-61. http://dx.doi.org/10.1038/206757a0

Bower, C. K., Sananikone, S., Bothwell, M. K., \& McGuire, J. (1999). Activity losses among T4 lysozyme charge variants after adsorption to colloidal silica. Biotechnol Bioeng, 64(3), 373-376. http://dx.doi.org/10.1002/(SICI)1097-0290(19990805)64:3<373::AID-BIT14>3.0.CO;2-J 
Bower, C. K., Xu, Q., \& McGuire, J. (1998). Activity losses among T4 lysozyme variants after adsorption to $\begin{array}{llll}\text { colloidal silica. } & \text { Biotechnol }\end{array}$ $\mathrm{http}: / / \mathrm{dx}$. doi.org/10.1002/(SICI)1097-0290(19980620)58:6<658::AID-BIT13>3.0.CO;2-3

Buonocore, G. G., Sinigaglia, M., Corbo, M. R., Bevilacqua, A., La Notte, E., \& Del Nobile, M. A. (2004). Controlled release of antimicrobial compounds from highly swellable polymers. J Food Prot, 67(6), 1190-1194.

Burgess, P. (1973). Lysozyme: History, Methods of Assay and Some Applications. Industrial Year Report, Hatfield Polytechnic.

Burgess, P., Appel, S. H., Wilson, C. A., \& Polk, H. C., Jr. (1994). Detection of intraabdominal abscess by serum lysozyme estimation. Surgery, 115(1), 16-21.

Caballero, M., Ruiz, R., Marquez de Prado, M., Seco, M., Borque, L., \& Escanero, J. F. (1999). Development of a microparticle-enhanced nephelometric immunoassay for quantitation of human lysozyme in pleural effusion $\begin{array}{lllll}\text { and } & \text { plasma. } J \text { Clin } & \text { Lab }\end{array}$ http://dx.doi.org/10.1002/(SICI)1098-2825(1999)13:6<301::AID-JCLA9>3.0.CO;2-3

Chang, H. M., Yang, C. C., \& Chang, Y. C. (2000). Rapid separation of lysozyme from chicken egg white by reductants and thermal treatment. J Agric Food Chem, 48(2), 161-164. http://dx.doi.org/10.1021/jf9902797

Chassy, B. M., \& Giuffrida, A. (1980). Method for the lysis of Gram-positive, asporogenous bacteria with lysozyme. Appl Environ Microbiol, 39(1), 153-158.

Cisani, G., Varaldo, P.E., Ingianni, A., Pompei, R., \& Satta, G., (1984). Inhibition of herpes simplex virus-induced cytopathic effect by modified hen egg-white lysozymes. Current Microbiology, 10, 35-40. http://dx.doi.org/10.1007/BF01576045

Clarke, A. J., \& Dupont, C. (1992). O-acetylated peptidoglycan: its occurrence, pathobiological significance, and biosynthesis. Can J Microbiol, 38(2), 85-91. http://dx.doi.org/10.1139/m92-014

Cross, M., Mangelsdorf, I., Wedel, A., \& Renkawitz, R. (1988). Mouse lysozyme M gene: isolation, characterization, and expression studies. Proc Natl Acad Sci U S A, 85(17), 6232-6236. http://dx.doi.org/10.1073/pnas.85.17.6232

Daly, S. (1938). Lysozyme of Nasal Mucus: Method of preparation and preliminary report on its effects on growth and virulence of common pathogens of paranasal sinuses. Arch Otolaryngol, 27(2), 189-196. http://dx.doi.org/10.1001/archotol.1938.00650030198007

Davis, C. S. (1971). Diagnostic value of muramidase. Postgrad Med, 49(4), 51-54.

De Roever, C. (1998). Microbiological Safety Evaluations and Recommendations on Fresh Produce. Food Control., 9, 321-347. http://dx.doi.org/10.1016/S0956-7135(98)00022-X

Devlieghere, F., Vermeiren, L., \& Debevere, J. (2004). New preservation technologies: possibilities and limitations. Int. Dairy J. 14, 273-285. http://dx.doi.org/10.1016/j.idairyj.2003.07.002

Dong, S., Shew, H. D., Tredway, L. P., Lu, J., Sivamani, E., Miller, E. S., \& Qu, R. (2008). Expression of the bacteriophage T4 lysozyme gene in tall fescue confers resistance to gray leaf spot $\&$ brown patch diseases. Transgenic Res, 17(1), 47-57. http://dx.doi.org/10.1007/s11248-007-9073-3

Ekins, R., \& Chu, F. (1997). Immunoassay \& other ligand assays: present status and future trends. J Int Fed Clin Chem, 9(3), 100-109.

Fett, J. W., Strydom, D. J., Lobb, R. R., Alderman, E. M., Vallee, B. L., Artymiuk, P. J., \& Redfield, C. (1985). Lysozyme: a major secretory product of a human colon carcinoma cell line. Biochemistry, 24(4), 965-975. http://dx.doi.org/10.1021/bi00325a024

Fleming, A. (1922). On a remarkable bacteriolytic element found in tissues \& secretions. Proc. Roy. Soc. London, 93, 306-317. http://dx.doi.org/10.1098/rspb.1922.0023

Fleming, A., \& Allison, V. D. (1922). Further observations on a bacteriolytic element found in tissues \& secretions. Proc. Roy. Soc. London. Series B, 44, 142-151. http://dx.doi.org/10.1098/rspb.1922.0051

Fleming, A., \& Allison, V. D. (1927). On the Development of Strains of Bacteria Resistant to Lysozyme Action \& the Relation of Lysozyme Action to Intracellular Digestion. J. Brit. Exp. Path., 8, 214-218. 
Francina, A., Cloppet, H., Guinet, R., Rossi, M., Guyotat, D., Gentilhomme, O., \& Richard, M. (1986). A rapid \& sensitive non-competitive avidin-biotin immuno-enzymatic assay for lysozyme. J Immunol Methods, 87(2), 267-272. http://dx.doi.org/10.1016/0022-1759(86)90541-7

Gill, A., Scanlon, T. C., Osipovitch, D. C., Madden, D. R., \& Griswold, K. E. (2011). Crystal structure of a charge engineered human lysozyme having enhanced bactericidal activity. PLoS One, 6(3), e16788. http://dx.doi.org/10.1371/journal.pone.0016788

Gorin, G., Wang, S. F., \& Papapavlou, L. (1971). Assay of lysozyme by its lytic action on M. lysodeikticus cells. Anal Biochem, 39(1), 113-127. http://dx.doi.org/10.1016/0003-2697(71)90467-2

Grutter, M. G., \& Matthews, B. W. (1982). Amino acid substitutions far from the active site of bacteriophage T4 lysozyme reduce catalytic activity and suggest that the $\mathrm{C}$-terminal lobe of the enzyme participates in substrate binding. J Mol Biol, 154(3), 525-535. http://dx.doi.org/10.1016/S0022-2836(82)80011-9

Han, J. H. (2000). Antimicrobial food packaging. Food Technol., 3, 56-65.

Hansen, N. E., Karle, H., Andersen, V., \& Olgaard, K. (1972). Lysozyme turnover in man. J Clin Invest, 51(5), 1146-1155. http://dx.doi.org/10.1172/JCI106907

Helal, R., \& Melzig, M. F. (2010). In vitro Effects of Selected Saponins on the Production and Release of Lysozyme Activity of Human Monocytic and Epithelial Cell Lines. Sci Pharm., 79(2), 337-349. http://dx.doi.org/10.3797/scipharm.1012-15

Herbert, S., Bera, A., Nerz, C., Kraus, D., Peschel, A., Goerke, C., ... Gotz, F. (2007). Molecular basis of resistance to muramidase and cationic antimicrobial peptide activity of lysozyme in staphylococci. PLoS Pathog, 3(7), e102. http://dx.doi.org/10.1371/journal.ppat.0030102

Hinnrasky, J., Chevillard, M., \& Puchelle, E. (1990). Immunocytochemical demonstration of quantitative differences in the distribution of lysozyme in human airway secretory granule phenotypes. Biol Cell, 68(3), 239-243. http://dx.doi.org/10.1016/0248-4900(90)90314-S

Houser, M. T. (1983). Improved turbidimetric assay for lysozyme in urine. Clin Chem, 29(8), 1488-1493.

Houser, M. T. (1983). Improved turbidimetric assay for lysozyme in urine. Clin. Chem., 29, 1488-1493

Ibrahim, H. R., Higashiguchi, S., Jugena, L. R., Kim, M., \& Yamamoto, T. (1996). A Structural Phase of Heat-Denaturated Lysozyme with Novel Antimicrobial Action. J. Agric. Food Chem., 44, 1416-1423. http://dx.doi.org/10.1021/jf9507147

Ibrahim, H. R., Kato, A., Kobayashi, K. (1991). Antimicrobial Effects of Lysozyme Against Gram-Negative Bacteria due to Covalent Binding of Palmitic Acid. J. Agric. Food Chem., 39, 2077-2083. http://dx.doi.org/10.1021/jf00011a039

Jollès, P. (1969). Lysozymes: a chapter of molecular biology. Angew. Chem. Int. Ed. Engl., 8(4), 227-239. http://dx.doi.org/10.1002/anie.196902271

Kim, D. T., Blanch, H. W., \& Radke, C. J. (2002). Direct imaging of lysozyme adsorption onto mica by atomic force microscopy. Langmuir., 18(15), 5841-5850. http://dx.doi.org/10.1021/la0256331

Klass, H. J., Hopkins, J., Neale, G., \& Peters, T. J. (1977). The estimation of serum lysozyme: a comparison of four assay methods. Biochem Med, 18(1), 52-57. http://dx.doi.org/10.1016/0006-2944(77)90048-5

Kuroki, R., Weaver, L. H., \& Matthews, B. W. (1999). Structural basis of the conversion of T4 lysozyme into a transglycosidase by reengineering the active site. Proc Natl Acad Sci U S A, 96(16), 8949-8954. http://dx.doi.org/10.1073/pnas.96.16.8949

Labuza, T. P., \& Breene, W. (1989). Application of 'active packaging' technologies for the improvement of shelf-life and nutritional quality of fresh and extended shelf-life foods. Bibl Nutr Dieta, (43), 252-259.

Le Jeune, A., Torelli, R., Sanguinetti, M., Giard, J. C., Hartke, A., Auffray, Y., \& Benachour, A. (2010). The extracytoplasmic function sigma factor $\mathrm{SigV}$ plays a key role in the original model of lysozyme resistance and virulence of Enterococcus faecalis. PLoS One, 5(3), e9658. http://dx.doi.org/10.1371/journal.pone.0009658

Lie, O., Evensen, O., Sorensen, A., \& Froysedal, E. (1989). Study on lysozyme activity in some fish species. Dis. Aquat. Org., 6, 1-5. http://dx.doi.org/10.3354/dao006001

Lollike, K., Kjeldsen, L., Sengelov, H., \& Borregaard, N. (1995). Purification of lysozyme from human neutrophils, and development of an ELISA for quantification in cells and plasma. Leukemia, 9(1), 206-209. 
Malmsten, M. (Ed.) (2003). Biopolymers at Interfaces (2nd ed.). New York: Marcel Dekker. http://dx.doi.org/10.1201/9780824747343

Markart, P., Faust, N., Graf, T., Na, C. L., Weaver, T. E., \& Akinbi, H. T. (2004). Comparison of the microbicidal \& muramidase activities of mouse lysozyme $\mathrm{M}$ and $\mathrm{P}$. Biochem $J, 380(\mathrm{Pt} 2), 385-392$. http://dx.doi.org/10.1042/BJ20031810

Marks, R. S., Cullen, D., Lowe, C., Weetall, H. H., \& Karube, I. (2007). Handbook of Biosensors and Biochips. Mississauga: John Wiley and Sons Ltd.

Marx, K. A. (2003). Quartz crystal microbalance: a useful tool for studying thin polymer films and complex biomolecular systems at the solution-surface interface. Biomacromolecules, 4(5), 1099-1120. http://dx.doi.org/10.1021/bm020116i

Matsumura, M., Becktel, W. J., Levitt, M., \& Matthews, B. W. (1989). Stabilization of phage T4 lysozyme by engineered disulfide bonds. Proc Natl Acad Sci $U$ S A, 86(17), 6562-6566. http://dx.doi.org/10.1073/pnas.86.17.6562

Matthews, B. W., \& Remington, S. J. (1974). The three dimensional structure of the lysozyme from bacteriophage T4. Proc Natl Acad Sci U S A, 71(10), 4178-4182. http://dx.doi.org/10.1073/pnas.71.10.4178

Mecitoglu, Ç., Yemeniciolu, A., Arslanolu, A., Elmacı, Z.S., Korel, F., \& Çetin, A.E. (2006). Incorporation of Partially Purified Hen Egg White Lysozyme into Zein Films for Antimicrobial Food Packaging. Food Research International., 39, 12-21. http://dx.doi.org/10.1016/j.foodres.2005.05.007

Meyer, K., Thompson, R., Palmer, J. W. \& Khorazo, D. (1936b). On the mechanism of lysozyme action. J. Biol. Chem., 113, 479-486.

Meyer, K., Thompson, R., Palmer, J. W., \& Khorazo, D. (1936a). The purification and properties of lysozyme. J. Biol. Chem., 113, 303-309.

Min, S., \& Krochta, J. M. (2005). Inhibition of Penicillium Commune by Edible Whey Protein Films Incorporating Lactoferrin, Lactoferrin Hydrosylate, and Lactoperoxidase Systems. J. Food Sci., 70, 87-94. http://dx.doi.org/10.1111/j.1365-2621.2005.tb07108.x

Mir, M. A. (1977). Lysozyme: a brief review. Postgrad Med J, 53(619), 257-259. http://dx.doi.org/10.1136/pgmj.53.619.257

Nakamura, S., Kato, A., \& Kobayashi, K. (1991) New antimicrobial characteristics of lysozyme-dextran conjugates. J. Agric. Food Chem., 39, 647-650. http://dx.doi.org/10.1021/jf00004a003

Nakamura, S., Kato, A., \& Kobayashi, K. (1992). Bifunctional lysozyme-galactomannan conjugate having excellent emulsifying properties \& bactericidal effect. J. Agric. Food Chem., 40, 735-739. http://dx.doi.org/10.1021/jf00017a005

Osserman, E. F., \& Lawlor, D. P. (1966). Serum and urinary lysozyme (muramidase) in monocytic and monomyelocytic leukemia. J Exp Med, 124(5), 921-952. http://dx.doi.org/10.1084/jem.124.5.921

O'Sullivan, C. K., \& Guilbgoldlt, G. G. (1999). Commercial quartz crystal microbalances-theory and applications. Biosens. Bioelectron., 14, 663-670. http://dx.doi.org/10.1016/S0956-5663(99)00040-8

Patil, R. S., Ghormade, V. V., \& Deshpande, M. V. (2000). Chitinolytic enzymes: an exploration. Enzyme Microb Technol, 26(7), 473-483. http://dx.doi.org/10.1016/S0141-0229(00)00134-4

Porstmann, B., Jung, K., Schmechta, H., Evers, U., Pergande, M., Porstmann, T., \& Krause, H. (1989). Measurement of lysozyme in human body fluids: comparison of various enzyme immunoassay techniques

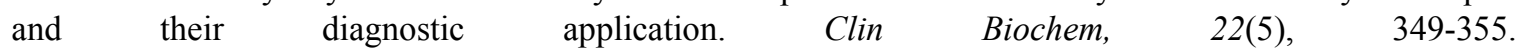
http://dx.doi.org/10.1016/S0009-9120(89)80031-1

Poteete, A. R., Rennell, D., Bouvier, S. E., \& Hardy, L. W. (1997). Alteration of T4 lysozyme structure by second-site reversion of deleterious mutations. Protein Sci, 6(11), 2418-2425. http://dx.doi.org/10.1002/pro.5560061115

Quintavalla, S., \& Vicini, L. (2002). Antimicrobial food packaging in meat industry. Meat Sci, 62(3), 373-380. http://dx.doi.org/10.1016/S0309-1740(02)00121-3

Ramanathan, A., Savol, A. J., Langmead, C. J., Agarwal, P. K., \& Chennubhotla, C. S. (2011). Discovering conformational sub-states relevant to protein function. PLoS One, 6(1), e15827. http://dx.doi.org/10.1371/journal.pone.0015827 
Reitamo, S., Lalla, M., \& Huipero, A. (1981). Serum lysozyme: evaluation of a nephelometric assay. Scand J Clin Lab Invest, 41(4), 329-332. http://dx.doi.org/10.3109/00365518109092053

Ronen, D., Eylan, E., Romano, A., Stein, R., \& Modan, M. (1975). A spectrophotometric method for quantitative determination of lysozyme in human tears: description and evaluation of the method and screening of 60 healthy subjects. Invest Ophthalmol, 14(6), 479-484.

Smith, C. A., \& Wood, E. J. (1991). Molecular and Cell Biochemistry: Biological Molecules. Chapman and Hall, London.

Song, Z. H., \& Hou, S. (2003). A new analytical procedure for assay of lysozyme in human tear and saliva with immobilized reagents in flow injection chemiluminescence system. Anal Sci, 19(3), 347-352. http://dx.doi.org/10.2116/analsci.19.347

Sulakvelidze, A., Alavidze, Z., \& Morris, J. G., Jr. (2001). Bacteriophage therapy. Antimicrob Agents Chemother, 45(3), 649-659. http://dx.doi.org/10.1128/AAC.45.3.649-659.2001

Suppakul, P., Miltz, J., Sonneveld, K., \& Bigger, S. W. (2003). Active packaging technologies with an emphasis on antimicrobial packaging and its applications. J. Food Sci., 68(2), 408-420. http://dx.doi.org/10.1111/j.1365-2621.2003.tb05687.x

Takahashi, K., Lou, X. F., Ishii, Y., \& Hattori, M. (2000). Lysozyme-glucose stearic acid monoester conjugate formed through the Maillard reaction as an antibacterial emulsifier. J Agric Food Chem, 48(6), 2044-2049. http://dx.doi.org/10.1021/jf990989c

Taylor, D. C., Cripps, A. W., \& Clancy, R. L. (1992). Measurement of lysozyme by an enzyme-linked immunosorbent assay. J Immunol Methods, 146(1), 55-61. http://dx.doi.org/10.1016/0022-1759(92)90048-X

Terry, J. M., Blainey, J. D., \& Swingler, M. C. (1971). An automated method for lysozyme assay. Clin Chim Acta., 35(2), 317-320. http://dx.doi.org/10.1016/0009-8981(71)90200-2

Trun, N., \& Trempy, J (2004). Fundamental Bacterial Genetics. Malden: Blackwell Publishing.

Tsugita, A., \& Inouye, M. (1968). Purification of bacteriophage T4 lysozyme. [Comparative Study]. J Biol Chem, 243(2), 391-397.

Van Dael, H. (1998). Chimeras of human lysozyme and alpha-lactalbumin: an interesting tool for studying partially folded states during protein folding. Cell Mol Life Sci, 54(11), 1217-1230. http://dx.doi.org/10.1007/s000180050249

Wohlkonig, A., Huet, J., Looze, Y., \& Wintjens, R. (2010). Structural relationships in the lysozyme superfamily: significant evidence for glycoside hydrolase signature motifs. PLoS One, 5(11), e15388. http://dx.doi.org/10.1371/journal.pone.0015388

Zhang, X. J., Baase, W. A., Shoichet, B. K., Wilson, K. P., \& Matthews, B. W. (1995). Enhancement of protein stability by the combination of point mutations in T4 lysozyme is additive. Protein Eng, 8(10), 1017-1022. http://dx.doi.org/10.1093/protein/8.10.1017

Zhang, X. J., Baase, W. A., Shoichet, B. K., Wilson, K. P., \& Matthews, B. W. (1995). Enhancement of protein stability by the combination of point mutations in T4 lysozyme is additive. Protein Eng, 8, 1017-1022. http://dx.doi.org/10.1093/protein/8.10.1017

\section{Copyrights}

Copyright for this article is retained by the author(s), with first publication rights granted to the journal.

This is an open-access article distributed under the terms and conditions of the Creative Commons Attribution license (http://creativecommons.org/licenses/by/3.0/). 